\title{
EFFECT OF REDUCED FAT LEVEL ON THE PHYSICAL AND CHEMICAL PROPERTIES OF BEEF PATTY BY USING POWDERED OAT MEAL
}

\author{
FATMA,A.I.ARAFA ${ }^{1}$ AND AHMED.T.EL-AKEL ${ }^{2}$
}

1. Meat and Fish Dept., Food Technology Research Institute, Agric.Res. Center, Giza.

2. Food Science\&Technology Dept.,Faculty of Agric., Cairo Univ.

(Manuscript received 23 June 2010)

\begin{abstract}
This study evaluated the effect of adding oat meal gel on physical, chemical, microbiological and sensory properties of lowfat $(<10)$ beef patties as compared to $20 \%$ fat in control patties. There was improvement represented by low cooking loss. During storage at- $18 \mathrm{C}^{0}$ for 6 months, there were decrease in non-soluble nitrogen reached to $1.58 \mathrm{~g} / 100 \mathrm{~g}$ for control sample, while was. 1.51 , 152 and $1.32 \mathrm{~g} / 100 \mathrm{~g}$ for patty samples with ( $8 \%, 13 \%$ and $18 \%$ oat meal gel ), and som increase of total volatile nitrogen. Also thiobarbituric acid value as influenced by different rates of fat substitutes at zero time and during storage, added oat meal to patties improved both of water holding capacity and plasticity while aerobic bacteria increased but did not reach to the rejected level, while E.coli was not detected for control or for the low-fat patty sample. Low- fat patties were found to show lower in degree of likeness in the taste but more juice than control $(P<0.05)$. Besides appearance, tenderness and color were not affected by the addition of $13 \%$ oat meal gel. Therefore oat fiber can be used successfully as a fat substitute in low - fat beef patties.
\end{abstract}

\section{INTRODUCTION}

Fats are important sources of certain nutrients and food energy and also contribute to food texture and satiety after eating .

Because of diet and health concerns, consumers have been urged to consume less fat and more foods containing complex carbohydrates. High fiber, law - fat foods tend to reduce risk of colon cancer, obesity, cardiovascular diseases and several other disorders. Because of this, fats have become a target for replacement in foods.

Ground beef is less 0 palatable and satisfying when fat decreases especially when fat is reduced to $5-10 \%$ Low - fat ground beef that has acceptable palatability is in demand, because ground beef with $20-30 \%$ fat contains a higher caloric density. Ground beef with fat ranging from $15-30 \%$ has been extended with soy protein in some studies. However, these studies did not explore textural modification of extenders in ground beef with 5 or $10 \%$ fat.

In general, previous research indicates that consumers seem to prefer ground beef patties containing $15 \%$ or more fat. 
Claus and Hant (1991) found that oat fiber, pea fiber, modified food starch and isolated soy protein could beneficially improve texture and reduce purge in low fat bologna. Egbert et al.(1991) reported that maximal consumer acceptance occurs at a $20 \%$ fat level in ground beef as a control. They developed a ground beef product containing less than $10 \%$ fat by using salt and hydrolyzed vegetable protein (2: 1) to increase beef flavor intensity, and $0.5 \%$ iota carrageenan and $10 \%$ water to increase moisture retention. This product had sensory characteristics very similar to controls. However, Hughes et al. (1997) investigated the effect of fat levels (5\%,12 \% and $30 \%)$, carrageenan and oat fiber on the hydration / binding properties, color and flavor characteristics of frankfurters. They found that decreasing fat content from $30 \%$ to $5 \%$ significantly increased cook loss and decreased both water holding capacity and emulsion stability . On the contrary, addition of carrageenan or oat fiber reduced cooking loss and increased both of water holding capacity and emulsion stability. They also found that carrageenan or oat fiber can partially offset some of the changes that occur in low-.fat frankfurters when added water replaces fat and protein level. The fat and salt content should be reduced to make meat products more acceptable to health conscious consumers.

Therefore, dietary guidelines for Americans suggested reducing sodium, fat and cholesterol in diets. Moreover, the American Health Association suggested limiting fat consumption to $<30 \%$ of calories, cholesterol to $<300 \mathrm{mg}$ and sodium to $<3 \mathrm{~g}$ daily (Matulis, et al., 1995 and El-Naggar, 1999).

The use of oat fiber source of B-glucan is useful for replacing saturated fats in food products have also achieved a very positive consumer image due to the health benefits that have been associated with lowering fats in foods products(Inglett et al. 2005). Due to the potential health benefits offered by glucan it become interesting to use as an ingredient in common meat products, such as a beef patty. Moreover, it have been reported the use of different types of oat fiber in the elaboration of several meat products as, hamburgers, sausages and meat balls.

Pinero et al. (2008) evaluated the effect of adding oat fiber sources of $\beta$-glucan $(13.45 \%)$ on physical, chemical microbiological and sensory traits of low. fat ( < $10 \%$ ) beef patties as compared to $20 \%$ fat control patties. They found that low fat patties were found to be of lower degree of likeness in the taste but more juice than control $(P<0.05)$. Besides, appearance, tenderness and color were not affected by the addition of oat's soluble fiber. Therefore oat fiber can be used successfully as a fat substitute in low - fat beef patties, while reduction of fat in finely ground meat products presents a number of difficulties in terms of appearance, flavor and texture, such products are less accepted by the consumer. (Vandendriessch, 2008). 
The general objective of this study was to determine physical, chemical, microbiological and sensory characteristics of beef patties formulated with the different ratio of oat meal jel

\section{Material and methods}

\section{Preparation of samples}

fifteen $\mathrm{kg}$ of lean beef were purchased form El-Harm abattoir in may 2009 Giza, Egypt and minced by using meat mince ( Home mince ). On the other hand the whole natural rolled oats were obtained from Isis Food Industries Company, Egypt. December 2008 . Beef back creamy white fat, was sourced from the same carcass, and non - meat, oat meal flour rehydrated (by boiling water added and stirred with oat and cooking about for $5 \mathrm{~min}$, stirring occasionally to form gel ).Meat ingredients, salt , sugar and spices. such as , garlic , oregano, pepper curry and corn starch were purchased from the local market in Giza, December 2008. Powdered oat meal flour was rehydrated (by mixing one part of powdered oat meal with two parts of boiling water ) before addition to the meat

Beef back fat and meat pieces previously trimmed of all visible adipose and connective tissues were stored at $-18 \mathrm{C}^{\circ}$ for 2 days in the polyethylene packs which were used after partial thawing at $4 \mathrm{C}^{\circ}$ and minced.

Four different samples of beef patties were formulated: Control with $20 \%$ fat and three low - fat patty formulas with different ratio of oat meal gel

The formula of different beef patties are presented in table (1) provided that oregano ( $0.2 \mathrm{~g})$, pepper $(0.07 \mathrm{~g})$ and curry $(0.07 \mathrm{~g})$ ( all $0.34 \mathrm{~g}$ ) were added for each $100 \mathrm{~g}$ of formula.

\section{Preparation of beef Pattie samples}

Table 1. Product formulation $\left(\mathrm{g} \mathrm{kg}^{-1}\right)$ for control and low - fat beef patty samples

\begin{tabular}{|c|c|c|c|c|}
\hline \multirow{2}{*}{ Ingredient } & \multirow{2}{*}{ Control } & \multicolumn{3}{|c|}{ Treatment low - fat } \\
\cline { 2 - 4 } & & $\mathrm{A} \%$ & $\mathrm{~B} \%$ & $\mathrm{C} \%$ \\
\hline Lean beef & 67.0 & 67.0 & 67.0 & 67.0 \\
Fat & 20.0 & 12.0 & 7.0 & 2.0 \\
Water & 8.7 & 8.7 & 8.7 & 8.7 \\
Salt & 1.3 & 1.3 & 1.3 & 1.3 \\
Sugar & 0.7 & 0.7 & 0.7 & 0.7 \\
Garlic & 0.4 & 0.4 & 0.4 & 0.4 \\
Oregano & 0.20 & 0.20 & 0.20 & 0.20 \\
Pepper & 0.07 & 0.07 & 0.07 & 0.07 \\
Curry & 0.07 & 0.07 & 0.07 & 0.07 \\
Starch & 1.9 & 1.9 & 1.9 & 1.9 \\
oat's gel & 0.00 & 8.0 & 13.0 & 18.0 \\
\hline
\end{tabular}

Ingredients of control and Low-fat patties ( Table 1) were mixed well. 
After preparation of each formula (A with $8 \%$ oat meal gel, formula B with $13 \%$ oat meal gel while $C$ with $18 \%$ oat meal gel), the patty samples were formed using burger form ( each sample $50 \mathrm{~g}$ ) and these samples were kept in a foam white tray ( 8 unit of beef burger in each one ) packed in polyethylene bags, then stored at - $18 \mathrm{C}^{\circ}$ for six months . the physical, chemical, microbiological and sensory properties were evaluated at zero and after $2,4,6$ months .

Cooking procedure:

Beef patties were thawed at $4 \pm 1 \mathrm{C}^{\circ}$, and then fried in corn oil by using a pan - frier for 2 min.

Chemical analysis:

Moisture , fat , protein ( T.NX 6.25) and ash were determined for oat meal , meat and patty samples according to : ( A.O.A.C, 1995 ) .while carbohydrate plus fiber was calculated by difference.

Total soluble nitrogen was extracted according to the method described by ElGharabawi and Dugan (1965), twenty $\mathrm{ml}$ of the extract was used for the determination of T.S.N by using micro kjeldahl method of A.O.A.C (1995)

Non - soluble nitrogen content (NSN) was calculated by the difference between total nitrogen and total soluble nitrogen. While total volatile nitrogen (T.V.N) was determined according to the method described by Winton and Winton (1958) Determination of thiobarbituric acid (TBA) value was carried out according to the method described by Kirk and Sawyer (1991) .

Physical analysis:

Water holding capacity and plasticity of patty samples were measured using the method of Grau and Hamm (1958) .

Cooking loss of prepared patty samples determined according El-Naggar (1999).For sensory evaluation, cooked patty samples were evaluated organoleptically immediately after cooking to test color, taste, odor, and overall acceptability by 10 panelists of Meat and Fish Department Staff, Food Technol. Inst., Agric. Res. center. the panel testers used a 10 score scale to evaluate the quality of patty samples. Statistical analyses of data was carried out by analysis of variance and least significant difference ( L.S.D ) at $5 \%$ level of significance as reported by Snedecor ( 1958 ).

\section{Judging scale was as follows}

Very good 8-9

$\begin{array}{lc}\text { Good } & 6-7 \\ \text { Fair } & 4-5 \\ \text { Poor } & 2-3 \\ \text { Very poor } & 0-1\end{array}$




\section{Microbiological analysis}

The total bacterial count ( TC ) and psychrotrophic bacteria were determined using nutrient agar medium as described by Difeco Manual (1984), while most probable number method ( MPN ) was used to numerate coliform group in Mac Conkey broth which also described by Difeco Manual (1984),

Results and discussion

\section{Chemical composition and chemical properties}

Chemical composition and quality attributes of oat meal and raw beef meat were tabulated in Table ( 2 ), these results showed that moisture, fat, ash , protein and carbohydrate + fiber contents of oat meal were $8.32 \%, 6.22 \%, 2.65 \%$, $14.89 \%$ and $76.24 \%$, respectively, as dry weight. While for beef meat were $75.08 \%, 12.44 \%, 6.02 \%$ and $81.54 \%$, respectively , these results are agreed with that of Kaarlehto Salovaara ( 2000 ) who reported that the chemical composition of whole oat flour was found to be $13.85-15.8 \%$ protein , 1.91 to $2.20 \%$ ash , 1.07 1.96 fiber and $7.0-8.01 \%$ fat and $65-75 \%$ starch. In the same table results showed that total volatile nitrogen and TBA value were $11.5 \mathrm{mg} / 100 \mathrm{~g}$ and $0.25 \mathrm{mg}$ malonaldyhide / $\mathrm{kg}$ sample, respectively, these results are in agreement with data published by Ali ( 2008 ) .

Data given in Table (3) show the chemical composition of the control and low - fat patty samples of formula $A, B$ and $C$ as influenced by different ratios of fat.

From the data shown in Table (3) it could be noted that moisture content of formulas $A, B$ and $C$ which contained oat's meal gel was higher than control samples at zero time, this result coincided with Bullock et al. ( 1994 ) who reported that high fat patties had lower moisture content than low -fat treatments. The moisture content was $57.35 \%$ of control sample and $61 \%, 63.7 \%, 67.7 \%$ in formulas A, B and C, respectively.

However, protein content of the control and low - fat sample were $19.3 \%$, $19.8 \%, 19.9$ and $20.05 \%$, respectively. From the same table it could be noticed that the percentage of ash content increased somewhat for all treatments of low -fat patties. These results are in agreement with El-Naggar, (1999) who found that all treatments containing additive ingredients as fat replaces had high ash content when compared to control sample. These results may be due to the high ash content of the fat replaces. From the same table, it could be noted that the substitutes incorporation increased the total carbohydrates content of different low - fat patty samples when compared to control patty. This may be due to the presence of carbohydrates in original additive (. El-Naggar ,1999). 


\section{Total soluble nitrogen}

The results of soluble nitrogen are presented in Table ( 4 ). It could be observed that the total soluble nitrogen of control patties was relatively higher it was $(0.9 \mathrm{~g} / 100 \mathrm{~g}$ sample) than low - fat patty samples formula A, B and C, they were $0.78,0.8$ and $0.87 \mathrm{~g} / 100 \mathrm{~g}$, respectively. The protein solubility decreased, possibly due to protein denaturation as well as to escape of soluble nitrogen with the separated drip. At the end of frozen storage, it was found that the decrease of control and formula $A, B$ and $C$ reached to $0.58,0.64,0.51$ and $0.57 \%$, respectively. This decrease may be due to denaturation of protein. as reported by Ali (2008).

\section{Non soluble nitrogen:}

Non soluble nitrogen (NSN) fraction contains some free amino acids, protein degradation products and other extractive nitrogenous compounds. It can be Table 2 . Chemical composition ( \% ) of fresh beef meat and oat meal

\begin{tabular}{|c|c|c|}
\hline \multirow{2}{*}{ Item } & Beef meat & Oat meal \\
\cline { 2 - 3 } & ND/W $^{-}$ & $\mathrm{D} / \mathrm{W}$ \\
\hline Moisture & 75.08 & 8.32 \\
Fat & 12.44 & 6.22 \\
Ash & 6.02 & 2.65 \\
Carbohydrate & - & 76.24 \\
Crud protein & 81.54 & 14.89 \\
T.S.N & 3.89 & \\
N.S.N & 9.15 & \\
T.V.N $(\mathrm{mg} / 100 \mathrm{~g})$ & 46.15 & \\
T.B.A $(\mathrm{mg}$ & & \\
malonaldehyde $/ \mathrm{kg})$ & 1.00 & \\
\hline
\end{tabular}

* Dry weight

Table 3 . Chemical composition ( $\%$ ) of the control and low - fat patty samples

\begin{tabular}{|c|c|c|c|c|}
\hline \multirow{2}{*}{ Item } & Control & \multicolumn{3}{|c|}{ Formula } \\
\cline { 2 - 5 } & & $\mathrm{A}$ & $\mathrm{B}$ & $\mathrm{C}$ \\
\hline moisture & 57.35 & 61.0 & 63.7 & 67.7 \\
Fat & 20.2 & 13.75 & 10.5 & 5.4 \\
Protein & 19.3 & 19.8 & 19.9 & 20.05 \\
Ash & 1.3 & 1.6 & 1.88 & 1.95 \\
carbohydrate & 1.85 & 3.85 & 4.02 & 4.9 \\
\hline T.V.N & 14.2 & 12.58 & 11.2 & 10.4 \\
T.B.A & 0.14 & 0.10 & 0.12 & 0.11 \\
WHC $\left(\mathrm{cm}^{2}\right)$ & 1.1 & 0.9 & 0.8 & 0.75 \\
Plasticity $\left(\mathrm{cm}^{2}\right)$ & 4.5 & 4.75 & 4.89 & 5.1 \\
Cooking loss & 23.2 & 20.5 & 18.5 & 17.9 \\
\hline
\end{tabular}


calculated by subtracting total nitrogen from total soluble nitrogen. Non soluble nitrogen was studied as an indication of proteolysis, the less the NSN, the less the proteolysis.

Results in Table ( 4 ) showed that NSN of control and low fat patties was $2.19 \mathrm{~g} / 100 \mathrm{~g}$ sample, while formulas A , B and C were 2.39 , 2.38 and $2.34 \mathrm{~g} / 100$ $\mathrm{g}$,respectively. From these results, it could be noted that extending storage time at $18 \mathrm{C}^{\circ}$ was accompanied by a gradual decrease in NSN content since it reached $1.58 \mathrm{~g}$ / $100 \mathrm{~g}$ sample for control sample while for formula A , B and C were 1.51, 1.52 and $1.32 \mathrm{~g} / 100 \mathrm{~g}$ sample, respectively. These results may be due to the microbiological activity and biochemical changes during storage of meat and meat products mainly responsible for the progressive decline of organoleptic quality. These results are in agreement with Ali (2008). The accumulation of protein breakdown products in meat tissue reflects the initial phase's autolytic deterioration, as well as later attributions through bacterial spoilage. Total volatile nitrogen was used as a measure of the extent of protein decomposition. The results given in Table (4) indicated the T.V.N content of control and low - fat patties as influenced by different rate fat substitute at zero time and during frozen storage at $-18 c^{\circ}$ for 6 months

From the results, it could be observed that the TVN was highest for control sample; it was $14.2 \mathrm{mg} / 100 \mathrm{~g}$ sample while was $12.58,11.2$ and $10.4 \mathrm{mg} / 100 \mathrm{~g}$ for the formula $A, B$ and $C$, respectively.

During frozen storage at $-18 \mathrm{c}^{\circ}$ the increase reached to $93.66 \%, 94.75 \%$, $122.14 \%$ and $130.77 \%$ of control and formula A, B and C, respectively after 6 months of frozen storage. Therefore by advancement of frozen storage, the TVN of all sample increased and this coincided with the decreasing of protein content during the frozen storage as reported by El-Naggar ( 1999 ). This increase in the patty samples during storage may be due to the effect of microorganisms as well as autolysis processes. Thiobarbituric acid (T.B.A) test is a condensation reaction between T.B.A and malonaldehyde, a product of fatty acid oxidation. T.B.A was taken as indicator of fat oxidation; the increment of this parameter means the development of fat oxidation.

Data given in Table ( 4 ) shows the values of TBA for control and low - fat meat patties as influenced by different ratios fat substitutes at zero time and during frozen storage ( at - $18 \mathrm{C}^{\circ}$ ) for 6 months. From these result it could be noted that control sample A, B and C samples revealed $0.1,0.12$ and $0.11 \mathrm{mg}$ malonaldehyde / $\mathrm{kg}$ sample, respectively. With advancement of frozen storage time the TBA values of all treatment increased indicating continues oxidation of lipids. However, the control treatment had the highest the increase reached $0.47 \mathrm{mg}$ malonaldehyde / $\mathrm{kg}$ at the 6 th month storage. This may be due to the high fat content of control sample. The rate of increase in TBA values differed with the fat level and type fat replace. (ElNaggar ,1999). 
This increase may be attributed to the psychotrophic bacteria which produce lipases that cause lipolytic activities of fat.

\section{Physical evaluation}

The water holding capacity (W.H.C) and plasticity were taken as indicator of water binding ability and tenderness respectively. The increasing of W.H.C as $\mathrm{cm}^{2}$ means the weakness of W.H.C., while the increasing of plasticity as $\mathrm{cm}^{2}$ means the increasing of tenderness. The W.H.C and plasticity as $\mathrm{cm}^{2} / 0.3 \mathrm{~g}$ of control and different formula patties were given in Table (5). The high W.H.C and plasticity (high tenderness) were found in the samples formula $A$, Band $C$ while the control sample was the least. Accordingly the added oat meal to patties improved the W.H.C and plasticity.

During storage of control and different formula patties (A, B and C) at $-18 \mathrm{C}^{\circ}$ for 6 months samples showed gradually decrease in the W.H.C and plasticity.

This might be attributed to the effect of freezing storage on denaturation of muscle protein and the loss of protein solubility. Also from physical characteristics of cooked beef patties a presented in the Table ( 5 ), cooking loss was decreased in low - fat beef patties, probably due to the ability of oat hydrocolloidal fiber to create a tridimensional matrix, holding not only water, but also fat added to the formulas avoiding losses of fat and water during cooking ( Warner \& Inglett, 1997 )..

\section{Microbiological evaluation}

Aerobic bacteria and the counts of psychotrophic \& E.coli of control and low fat beef patty during storage at $-18{ }^{\circ} \mathrm{C}$ for 6 months are shown inTtable (6). From this table, it could be noted that there were continuous increase in the total microbial counts but this increase did not reach to the rejected level $\left(10^{6} \mathrm{CFU} / \mathrm{g}\right)$ in all tested samples even at the end of storage periods. These result are in agreement with Covenin ( 1998 ) who reported that after frozen storage aerobic bacteria was less than $10^{6} \mathrm{CFU} / \mathrm{g}$ While E.coli was not detected in control or of the low-fat patty samples

\section{Sensorial attributes}

The results obtained for the sensory analysis are presented in Table (7), it could be observed that the beef patties containing oat's meal fiber were found to be significantly $(p<0.05)$ juicier than the control, which could be attributed to the increased moisture of the product during cooking. These results are in agreement with Pszezola ( 1991 ) who reported that the oat fiber has the ability to retain moisture and prevents meats from drying out when cooked as compared to the control, while it had a lower sensory scores $(p<0.05)$. Pinero, et al. (2008) showed that the decrease of fat level in meat products result in reduction of the flavor intensity. 
Table 4. Effect of oat meal on some quality attributes of control and low-beef Pattie samples during storage at $-18^{\circ} \mathrm{C}$ for 6 months

Control

\begin{tabular}{|c|c|c|c|c|c|c|}
\hline \\
\hline Storage & T.P & T.N & TSN & NSN & TVN & TBA \\
\hline 0 & 19.3 & 3.09 & 0.90 & 2.19 & 14.2 & 0.14 \\
\hline 2 & 17.5 & 2.8 & 0.64 & 2.16 & 18.0 & 0.26 \\
\hline 4 & 15.63 & 2.5 & 0.60 & 1.9 & 22.5 & 0.34 \\
\hline 6 & 13.5 & 2.16 & 0.58 & 1.58 & 27.5 & 0.47 \\
\hline \multicolumn{7}{|c|}{ Formula A $8 \%$ gel } \\
\hline 0 & 19.8 & 3.17 & 0.78 & 2.39 & 12.58 & 0.1 \\
\hline 2 & 17.81 & 2.85 & 0.85 & 2.00 & 16.0 & 0.17 \\
\hline 4 & 14.38 & 2.30 & 0.69 & 1.61 & 20.45 & 0.23 \\
\hline 6 & 13.44 & 2.15 & 0.64 & 1.51 & 24.5 & 0.28 \\
\hline \multicolumn{7}{|c|}{ Formula B $13 \%$ gel } \\
\hline 0 & 19.9 & 3.18 & 0.80 & 2.38 & 11.2 & 0.12 \\
\hline 2 & 17.63 & 2.82 & 0.71 & 2.11 & 15.5 & 0.13 \\
\hline 4 & 15.00 & 2.4 & 0.58 & 1.82 & 20.6 & 0.21 \\
\hline 6 & 12.69 & 2.03 & 0.51 & 1.52 & 24.88 & 0.25 \\
\hline \multicolumn{7}{|c|}{ Formula C $18 \%$ gel } \\
\hline 0 & 20.05 & 3.21 & 0.87 & 2.34 & 10.4 & 0.11 \\
\hline 2 & 17.19 & 2.75 & 0.83 & 1.92 & 15.0 & 0.2 \\
\hline 4 & 14.63 & 2.34 & 0.70 & 1.64 & 19.0 & 0.28 \\
\hline 6 & 11.81 & 1.89 & 0.57 & 1.32 & 24.0 & 0.36 \\
\hline
\end{tabular}

T.P:Total protein

T.N : Total nitrogen

T.S.N : Total soluble nitrogen

N.S.N: Non soluble nitrogen

T.V.N : Total volatile nitrogen

T.B.A : Thiobarbituric acid 
EFFECT OF REDUCED FAT LEVEL ON THE PHYSICAL AND CHEMICAL PROPERTIES OF BEEF PATTY BY USING POWDERED OAT MEAL 
Table 7. Mean score of organoleptic properties of patty samples during storage period for 6 months at $-18^{\circ} \mathrm{C}$

\begin{tabular}{|c|c|c|c|c|c|c|c|c|c|c|}
\hline \multirow{2}{*}{$\begin{array}{c}\text { Storage } \\
\text { period } \\
\text { (months) }\end{array}$} & \multicolumn{5}{|c|}{ Control } & \multicolumn{5}{|c|}{ Formula A } \\
\hline & Color & Taste & Odor & Texture & Juiciness & Color & Taste & Odor & Texture & Juiciness \\
\hline 0 & $8.7^{\mathrm{Aa}}$ & $8.8^{\mathrm{Aa}}$ & $8.9^{\mathrm{Aa}}$ & $8.7^{\mathrm{Aa}}$ & $8.2^{\mathrm{Aa}}$ & $8.6^{\text {Aa }}$ & $8.5^{\text {Aa }}$ & $8.8^{\mathrm{Aa}}$ & $8.6^{\mathrm{Aa}}$ & $8.4^{\mathrm{Ba}}$ \\
\hline 2 & $8.1^{\mathrm{Ab}}$ & $8.7^{\mathrm{Aa}}$ & $8.6^{\text {Aa }}$ & $8.1^{A b}$ & $7.9^{A b}$ & $7.8^{\mathrm{ABb}}$ & $8.2^{\mathrm{Bab}}$ & $8.5^{\mathrm{ABa}}$ & $7.8^{\mathrm{ABb}}$ & $8.2^{\mathrm{Ba}}$ \\
\hline 4 & $7.5^{\mathrm{Ac}}$ & $8.5^{\mathrm{Aab}}$ & $7.7^{\mathrm{Ab}}$ & $7.4^{\mathrm{AC}}$ & $7.2^{\mathrm{Ac}}$ & $7.3^{\mathrm{Ac}}$ & $8.0^{\mathrm{BbC}}$ & $7.1^{\mathrm{Bb}}$ & $7.2^{\mathrm{ABC}}$ & $7.6^{\mathrm{Ab}}$ \\
\hline \multirow[t]{2}{*}{6} & $6.8^{\mathrm{Ad}}$ & $8.1^{A b}$ & $6.6^{\mathrm{AC}}$ & $6.6^{\mathrm{Ad}}$ & $6.1^{\mathrm{Ad}}$ & $6.6^{\mathrm{ABd}}$ & $7.8^{\mathrm{AC}}$ & $6.2^{\mathrm{ABC}}$ & $6.6^{\mathrm{Ad}}$ & $6.4^{A C}$ \\
\hline & \multicolumn{5}{|c|}{ Formula B } & \multicolumn{5}{|c|}{ Formula C } \\
\hline 0 & $7.8^{\mathrm{Ba}}$ & $7.9^{\mathrm{Ba}}$ & $8.6^{\text {Aa }}$ & $7.9^{\mathrm{Ba}}$ & $8.6^{\mathrm{Ba}}$ & $7.7^{\mathrm{Ba}}$ & $6.9^{\mathrm{Ca}}$ & $8.2^{\mathrm{Ba}}$ & $7.7^{\mathrm{Ba}}$ & $8.7^{\mathrm{Ba}}$ \\
\hline 2 & $7.7^{\mathrm{ABa}}$ & $7.7^{\mathrm{Ca}}$ & $8.3^{\mathrm{ABa}}$ & $7.8^{\mathrm{ABa}}$ & $8.4^{\mathrm{BCa}}$ & $7.5^{\mathrm{Ba}}$ & $6.7^{\mathrm{Da}}$ & $8.1^{\mathrm{Ba}}$ & $7.4^{\mathrm{Ba}}$ & $8.1^{\mathrm{Cb}}$ \\
\hline 4 & $7.2^{\mathrm{ABb}}$ & $7.5^{\mathrm{ca}}$ & $6.9^{\mathrm{Bb}}$ & $7.2^{\mathrm{ABb}}$ & $7.8^{\mathrm{Ab}}$ & $6.8^{\mathrm{Bb}}$ & $6.5^{\mathrm{Dab}}$ & $6.7^{\mathrm{Bb}}$ & $6.8^{\mathrm{Bb}}$ & $7.5^{\mathrm{BC}}$ \\
\hline 6 & $6.5^{\mathrm{ABC}}$ & $6.9^{\mathrm{Bb}}$ & $6.1^{A B C}$ & $6.5^{A C}$ & $6.7^{A C}$ & $6.2^{B C}$ & $6.2^{\mathrm{Cb}}$ & $5.8^{\mathrm{BC}}$ & $6.4^{\mathrm{Ab}}$ & $6.5^{\mathrm{Bd}}$ \\
\hline
\end{tabular}

Mean values in the same row (as a capital letter), while column (as a small letter). Means with the same letter are not significantly different within the same column at $(p<0.05)$ 


\section{CONCLUSION}

Oat fiber in gel form at $13 \%$ level can be effectively used as a functional ingredient in low-fat beef patties by enhancing moisture and fat entrapment, largely responsible for the observed increase in cooking yield and help on maintaining the uniform tenderness of the product. The final product gave satisfaction to local consumers and remained stable without any noticeable loss of microbiological quality under frozen storage.

\section{REFERENCES}

1. Ali , M . A . I. 2008. Effect of processing and cooking methods on chemical, biological and microbiological properties of low - fat meat products. Ph . D. Thesis , Fac. of Agric ., Cairo Univ.

2. A.O.A.C.1995. Official Methods of Analysis. Association of Official Analytical Chemists $16^{\text {th }}$ ed., Virginia,U.S.A.

3. Bullock , K . B , Huffman , D.L and Egbert , W.R. 1994. Storage stability of low fat ground beef made with lower value cuts of beef . J . Food Sci ., 59 ( 1 ) : 6 9.

4. Claus , J.R. and Hunt, M.C. 1991. low - fat, high added water bologna formulated with texture modifying ingredients . J. Food Sci. , $56: 643-647,652$.

5. Convenin. 1998. Comision Venezolana de Normas Industriales. Hamburguesas. ( $2127: 1998$ ).

6. Difco Manual. 1984. " Dehydrated Culture and Reagent's for Microbiology " $10^{\text {th }}$ Ed., Difco laboratories, Detroit, M.I. , U.S.A : $476-478$

7. Egbert,W.R., Huffman, D.I., Chen, C.M. and Dylewski, D.P.1991. Development of low-fat ground beef . J .Food Technol.,45 ( 6 ): 66-68, 70, 71,75.

8. El-Gharabawi, M.I. and Dugan . L.R. 1965. Stability of mitrogenous compounds and lipids during storage of freeze - dried raw beef . J . Food Sci., 30 (5) : 817 822.

9. El-Naggar , S.M. 1999. Production and evaluation of low-fat meat products . M.Sc. Thesis, Faculty of Agriculture, Cairo University , A.R.E .

10. Grau , R . and F. Hamm. 1958. Ufer dos Wasserbndung severmogen des sausagetier muckels II . Ufer die bestimmug der Wasserbindung des muscles, Z . lebensmittel untersuch . und Forshung , $105: 446-460$. 
11. Hughes, E. , S. Cofrades and D.J. Troy. 1997. Effects of fat level, oat fibre and carrageen on frankfurters formulated with 5,12 and $30 \%$ fat. Meat Sci. , 45 ( 3 ) : $273-281$.

12. Inglett , C., S. Peterson, C. Carriere and S. Maneepun. 2005. Rheological , texture and sensory properties of Asian noodles containing oat cereal hydrocolloid Food Chemistry, 90 ( 182$): 1-8$.

13. Kaarlehto , T. and H. Salovaara. 2000. Effect of Kiln during on falling number of oats. Cereal Chem. , 77 ( 2 ) : $177-180$.

14. Kirk, R.S. and R. Sawyer. 1991. Pearson's composition and Analysis of Food. $9^{\text {th }}$ edition John Wiley and Sons Inc., 605 third Avenue, New York. NY 10158 Public Health Association. Washington, D.C., U.S.A ., PP . 325 - 369.

15. Piṇero , M.P., N., parra , N., N., Huerta - Leidenz, L., Arenas de Morenopin, M., Ferrer, S. Araujo and Y.Baeboza . 2008. Effect of oat's soluble fiber ( $\beta$ - glucan ) as a fat replaces on physical , chemical , microbiological and sensory properties of low - fat beef patties. Meat science, $80: 675-680$.

16. Pszezola, D. 1991. Oat - bran based ingredient blend replaces fat in ground beef and pork sausage. Food Technology , $45: 60$.

17. Snedecor , G.W. 1958.

18. Statistical Method . The Iowa state University Ress . Ames lowa U.S.A .

19. Warner , K . and G .Inglett .1997. Flavor and texture characteristics of food containing $\mathrm{z}$-trim corn and oat fibers as fat and flour replace. Cereal Food World , 42 ( 10$): 821-825$.

20. Winton, A.L. and R.B. Winton. 1958. Okoloff Magenesium Oxid Distillation Volumetric Method. The Analysis oF Food , 848 , John , New York , Chapman and Hall , London. 
تأثثير خفض نسبه الدهن علي الخواص الطبيعية و الكيماوية بأستخدام مطحون الثوفان في باتيه اللحم البقري

د. فاطمة عبد المنعم إبراهيم عرفه11 ، لــ أحمد توفيق العاقل2 ا ـ قسم بحوت تكنولوجيا اللحوم و الأسماك - معهز بحوث تكنولوجيا الأغذية - مركز البحوث

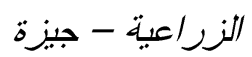
r r قسم علوم الأغذية و التكنولوجيا - كلية النزراعة - جامعة القاهرة

تم دراسة تأثير خفض نسبة الدهن ( > 10 \% ) بإضافه جل مطحون الثوفان على الخواص

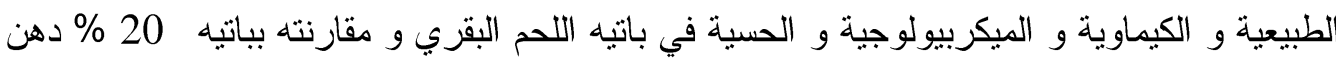

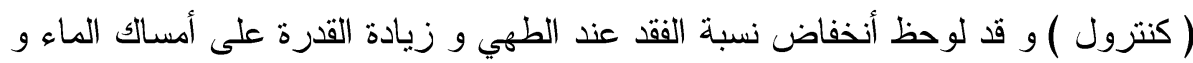

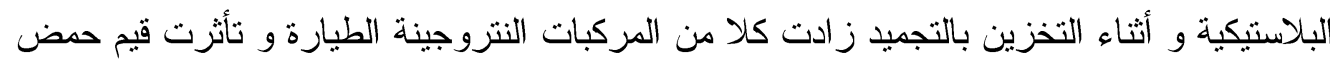

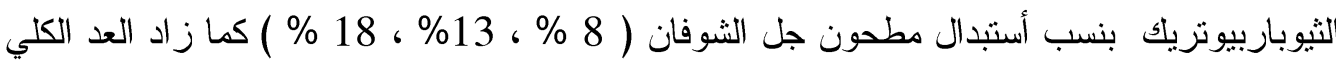

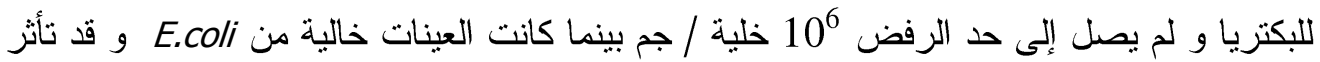

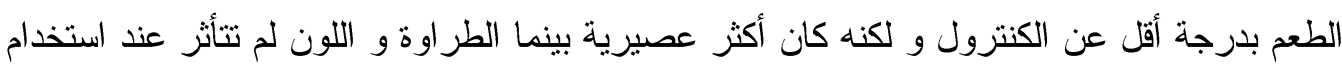

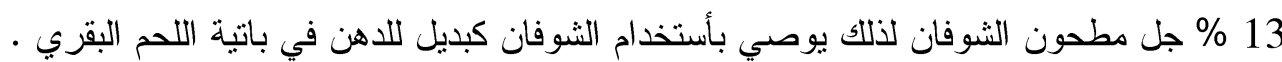

